\title{
Assessing the Influence of Sowing Windows on Growth and Yield of Small Millets
}

\author{
M. Jyostna Kiranmai*, S. Saralamma and C. V. Chandra Mohan Reddy
}

Regional Agricultural Research Station, Nandyal, Kurnool Dist. (A.P), Andhra Pradesh, India

*Corresponding author

\section{A B S T R A C T}

\section{Keywords}

Foxtail millet, Dates of sowing, Growth, Yield

Article Info

Accepted:

10 January 2021

Available Online:

10 February 2021
Small millets are important crops cultivated in input farming systems by resource poor farmers. Nutri cereals (Small millet crops) are neglected crops. As, sowing time has a major role in determining the yield of crops the present experiment was taken up to assess the impact of sowing windows on growth and yield of small millets. The site of experimentation was Regional Agricultural Research, station, Nandyal during kharif, 2019. The design used for experimentation is split-plot. The treatments consisted of 3 small millet crops littlemillet, foxtailmillet and proso millet with 6 sowings windows July $1^{\text {st }} \mathrm{FN}$, July $2^{\text {nd }} F N$, August $1^{\text {st }} F N$, August $2^{\text {nd }} F N$, September $1^{\text {st }} F N$ and September $2^{\text {nd }} F N$. Crop sown during July $2^{\text {nd }} \mathrm{FN}$ had the maximum, plant height $(122 \mathrm{~cm})$, thousand grains weight $(4.97 \mathrm{~g})$ and grain yield $\left(2455 \mathrm{Kg} \mathrm{ha}^{-1}\right)$ as compared with other sowing dates. The interaction effect between small millet crops and sowing windows showed that the economic yield (grain yield) of foxtail millet and prosomillet were found to be highest when sown during July $2^{\text {nd }} \mathrm{FN}(3530 \mathrm{~kg} / \mathrm{ha}$ and $1876 \mathrm{~kg} / \mathrm{ha}$ respectively). But for little millet the highest grain yield was observed when sown at July $1^{\text {st }} \mathrm{FN}(2024 \mathrm{~kg} / \mathrm{ha})$.

\section{Introduction}

Small millets are traditional and unique crops of drytracts of India. Small millets are cultivated both for food and fodder purpose. They are traditionally indispensable component of dry farming system in India. Small millets, though called poor man's crops are nutritionally comparable and are even superior to other cereals especially with respect to amino acids, proteins, phosphorous, thiamine and other nutrients, besides high calorific value, the slow digestible carbohydrates make food for long sustenance
Small millets helps to alleviate malnutrition and to enhance nutritional security and breaks excessive dependence on few major food crops for this purpose. Small millets widely cultivated in india are finger millet [Eleusine coracana (L.)], little millet Panicum sumatrance), kodo millet [Paspalum scrobiculatum (L.)], foxtail millet [Setaria italica (L.)], barnyard millet [Echinochloa frumentacea (L.)] and proso millet [Panicum miliaceum (L.)]. Besides the nutritional importance of small millets, they have additional advantages like, small millets varieties having short duration can fit into any 
cropping systems even in orchards, widely spaced crops, the water consumption of small millets is comparatively low compared to other cereals, less prone to pests and diseases. Small millets are now becoming popularized and their now coming back to the plates of common peoples. Small millets are regaining their importance in agriculture. A change is consumption pattern is observed. These small millets are generally grown under rainfed conditions in low fertility conditions the average productivity is very low. Keeping in view of nutritional advantage of there is a rapid increase in demand. In this connection research on the best management practices has to be emhasized. Sowing time has an important role on production and productivity of crops. Crops sown at optimum time has the advantage of being exposed to congenial climate at all growth stages and this inturns improves the productivity of crop. This is in similar with findings of Upadhyay et al., (2001) and stated that the bajra sown at exact window without any delay had given higher grain yield. Reduction in yield was observed under delayed sowings. Timely sowing generally ensures sufficient time for root development and vegetative growth and has the advantage to escape from peak period of crop weed competition thus provided optimum harvesting of available soil nutrient and radiant energy. (Thompson and Kelly, 1957), Crop sown late is normally affected by moisture stress. Generally small millet crops are grown during july, Due to change in climate scenario there is a requirement to revisit the sowing time for small millets. The present research has been taken to assess the performance of 3 small millets to different sowings window and to find out the best time for small millets.

\section{Materials and Methods}

Field experiment entitled "Assessing the influence of sowing windows on growth and yield of small millets" was carried during kharif, 2019 at Regional Agricultural Research Station, Nandyal. The design used for laying of experiment is split-plot design with three replications. Main plots consists of three small crops viz., Foxtail millet, little millet and proso millet. Sub plots consists of six sowing windows i.e., July $1^{\text {st }} \mathrm{FN}$, July $2^{\text {nd }}$ FN, August $1^{\text {st }}$ FN, August $2^{\text {nd }} F N$, September $1^{\text {st }} \mathrm{FN}$, September $2^{\text {nd }} F N$. The soils are deep vertisols. The experimental site is located at $18^{0} 29$ ' $N$ latitude, $78^{0} 29^{\prime}$ E longitude and at an altitude of 202 above MSL, in the scarce rainfall zone of Andhra Pradesh. The soils are alkaline in reaction (8.2), low in nitrogen (180 $\mathrm{kg} \mathrm{ha}{ }^{-1}$ ), medium in available phosphorous (48.2 $\mathrm{kg} \mathrm{ha}^{-1}$ ) and potassium (366 kg ha ${ }^{-1}$ ). The crops were raised by following package of practices of respective crops. $20 \mathrm{~kg}$ Nitrogen and $20 \mathrm{~kg} \mathrm{P}_{2} \mathrm{O}_{5}$ were applied basally at the time of sowing, remaining $20 \mathrm{~kg} \mathrm{~N}$ were applied at 25 DAS. During kharif season, the maximum temperature ranged between $35.8^{0} \mathrm{C}$ to $30.1^{0} \mathrm{C}$ with an average of $32.5^{\circ} \mathrm{C}$. Whereas, the minimum temperature during crop season ranged between $19.6^{\circ} \mathrm{C}$ to $25.6^{\circ} \mathrm{C}$ with an average of $22.9^{\circ} \mathrm{C}$. the maximum relative humidity ranged between $90 \%$ to $80.5 \%$ with an average of $86.6 \%$. whereas, the minimum relative humidity ranged between $50.5 \%$ to $71.3 \%$ with an average of $61.1 \%$.

Average wind speed varied from $0.1 \mathrm{~km} / \mathrm{hr}$ to $9.9 \mathrm{~km} / \mathrm{hr}$ with an average of $4.5 \mathrm{~km} / \mathrm{hr}$. Evaporation ranged from $2 \mathrm{~mm} /$ day to 6.3 $\mathrm{km} / \mathrm{hr}$ with an average of $3.2 \mathrm{~km} / \mathrm{hr}$. The gross plot size was $4.5 \mathrm{~cm} \mathrm{X} 3.0 \mathrm{~cm}$ and net plot sizes was $2.4 \mathrm{~m} \times 4.2 \mathrm{~m}$. All the cultivars are were dibbled at a spacing of $30 \mathrm{cmX} 10 \mathrm{~cm}$ during kharif, 2019. During crop growth period an total amount of $913.8 \mathrm{~mm}$ of rainfall was received in 43 rainy days. A common spacing of $30 \mathrm{~cm} X 10 \mathrm{~cm}$ was maintained for all small millet crops. Sowings were done on 13.07.2019, 26.07.2019, 
13.08.2019, $\quad 30.08 .2019, \quad$ 13.09.2019, 30.09.2019 at different fortnight intervals from July $1^{\text {st }} \mathrm{FN}$ to September $2^{\text {nd }} \mathrm{FN}$

\section{Results and Discussion}

\section{Plant height}

The plant height was not significantly influenced both by the small millet crops and sowing windows. Numerically the highest plant height was recorded with little millet $(122 \mathrm{~cm})$ followed by foxtail millet $(119 \mathrm{~cm})$ and the lowest were noticed in proso millet $(1114 \mathrm{~cm})$. Among sowing windows maximum plant height $(123 \mathrm{~cm})$ was found when sown during july $1^{\text {st }} \mathrm{FN}$. These results are in confirmation with the findings of Patil (2018) (Table 1).

\section{0 seed weight}

Significantly higher 1000 seed weight was found with proso millet $(4.97 \mathrm{~g})$ and was comparable with foxtail millet $(3.21 \mathrm{~g})$ and the lowest test weight was noticed with little millet $(2.34 \mathrm{~g})$. Among different sowing windows the highest was found with S2 i.e. sowing during July $2^{\text {nd }} \mathrm{FN}(3.65 \mathrm{~g})$ and it was on par with all other sowing windows

Table.1 Performance of small millets as influenced sowing windows (2019-20)

\begin{tabular}{|c|c|c|c|c|c|c|c|}
\hline Treatments & $\begin{array}{c}\text { Plant } \\
\text { height } \\
(\mathbf{c m})\end{array}$ & $\begin{array}{l}1000 \text { seed } \\
\text { weight } \\
\text { (g) }\end{array}$ & $\begin{array}{l}\text { No. of } \\
\text { Productive } \\
\text { tillers }\end{array}$ & $\begin{array}{c}\text { Days } \\
\text { to } \\
\text { maturity }\end{array}$ & $\begin{array}{c}\text { Harvest } \\
\text { index } \\
(\%)\end{array}$ & $\begin{array}{l}\text { Grain } \\
\text { yield } \\
\text { (kg/ha) }\end{array}$ & $\begin{array}{c}\text { Straw } \\
\text { yield } \\
\text { (kg/ha) }\end{array}$ \\
\hline \multicolumn{8}{|l|}{ Main plots } \\
\hline 1.Foxtail millet & 119 & 3.21 & 2.67 & 74 & 45.38 & 2679 & 3186 \\
\hline 2.Little millet & 122 & 2.34 & 5.67 & 92 & 40.88 & 1823 & 2628 \\
\hline 3.Proso millet & 114 & 4.97 & 5.61 & 75 & 40.11 & 1564 & 2337 \\
\hline SEm \pm & 3.3 & 0.06 & 0.21 & 0.18 & 1.24 & 81.23 & 88.21 \\
\hline $\mathrm{CD}(\mathbf{P}=\mathbf{0 . 0 5})$ & NS & 0.27 & 0.81 & 0.74 & NS & 316.57 & 346.59 \\
\hline CV $(\%)$ & 8.31 & 5.93 & 6.44 & 2.68 & 5.26 & 11.96 & 9.74 \\
\hline \multicolumn{8}{|l|}{ Sub plots } \\
\hline 1. July $1^{\text {st }}$ FN & 123 & 3.56 & 5.12 & 79 & 43.88 & 2180 & 2882 \\
\hline 2. July $2^{\text {nd }}$ FN & 119 & 3.65 & 5.46 & 81 & 44.11 & 2455 & 2987 \\
\hline 3.Aug $1^{\text {st }} \mathrm{FN}$ & 120 & 3.59 & 4.58 & 80 & 42.11 & 2058 & 2757 \\
\hline 4.Aug $2^{\text {nd }}$ FN & 119 & 3.53 & 4.44 & 81 & 41.66 & 1958 & 2692 \\
\hline 5.Sep 1st FN & 119 & 3.41 & 4.27 & 79 & 41.33 & 1800 & 2553 \\
\hline 6. Sep $2^{\text {nd }}$ FN & 113 & 3.32 & 4.04 & 80 & 40.66 & 1681 & 2434 \\
\hline SEm \pm & 4.5 & 0.09 & 0.45 & 0.58 & 1.17 & 87.14 & 89.06 \\
\hline $\mathrm{CD}(\overline{\mathbf{P}}=\mathbf{0 . 0 5})$ & NS & 0.271 & 0.16 & NS & NS & 251.62 & 258.71 \\
\hline $\mathrm{CV}(\%)$ & 8.07 & 5.68 & 7.58 & 3.03 & 5.82 & 9.14 & 6.99 \\
\hline \multicolumn{8}{|l|}{ Interaction CXS } \\
\hline SEm \pm & 2.9 & 0.12 & 0.49 & 0.45 & 3.02 & 139.66 & 110 \\
\hline $\mathrm{CD}(\overline{\mathbf{P}}=\mathbf{0 . 0 5})$ & NS & NS & NS & NS & NS & 340.51 & NS \\
\hline \multicolumn{8}{|l|}{ Interaction SXC } \\
\hline SEm \pm & 4.9 & 0.15 & 0.32 & 0.93 & 2.23 & 112.89 & 109 \\
\hline $\mathrm{CD}(\overline{\mathrm{P}}=\mathbf{0 . 0 5})$ & NS & NS & NS & NS & NS & 360.18 & NS \\
\hline
\end{tabular}


Table.2 Interaction effect for grain yield (kg/ha) as influenced by sowing windows

\begin{tabular}{|l|c|c|c|c|c|c|c|}
\hline & $\begin{array}{c}\mathbf{J u l y ~ 1}^{\text {st }} \\
\text { FN }\end{array}$ & $\begin{array}{c}\text { July } \\
\mathbf{2}^{\text {nd }} \mathbf{F N}\end{array}$ & Aug 1 & Aug 2 & Sept 1 & Sep & Mean \\
\hline Foxtail millet & 2765 & 3530 & 2715 & 2518 & 2370 & 2176 & 2679 \\
\hline Little millet & 2024 & 1958 & 1853 & 1829 & 1701 & 1575 & 1823 \\
\hline Proso millet & 1752 & 1876 & 1604 & 1526 & 1330 & 1293 & 1563 \\
\hline Mean & 2180 & 2455 & 2058 & 1958 & 1800 & 1681 & \\
\hline $\begin{array}{l}\text { Interaction } \\
\text { CXS }\end{array}$ & & & SEm \pm & 139.69 & CD (P=0.05) & 340.51 & \\
\hline
\end{tabular}

Table.3 Economics of small millets as influenced by sowing windows

\begin{tabular}{|l|c|c|c|}
\hline Treatments & $\begin{array}{c}\text { Gross returns } \\
\text { (Rs/ ha) }\end{array}$ & $\begin{array}{c}\text { Net returns } \\
\text { (Rs./ ha) }\end{array}$ & B:C ratio \\
\hline C1S1 & 52470 & 32920 & 2.68 \\
\hline C1S2 & 66356 & 48456 & 3.71 \\
\hline C1S3 & 51472 & 31922 & 2.63 \\
\hline C1S4 & 47855 & 29955 & 2.67 \\
\hline C1S5 & 45045 & 25495 & 2.30 \\
\hline C1S6 & 41520 & 23620 & 2.32 \\
\hline C2S1 & 38750 & 19200 & 1.98 \\
\hline C2S2 & 37488 & 19588 & 2.09 \\
\hline C2S3 & 35459 & 15909 & 1.81 \\
\hline C2S4 & 34973 & 17073 & 1.95 \\
\hline C2S5 & 32655 & 13105 & 1.67 \\
\hline C2S6 & 30274 & 12374 & 1.69 \\
\hline C3S1 & 33497 & 13947 & 1.71 \\
\hline C3S2 & 35915 & 18015 & 2.01 \\
\hline C3S3 & 30833 & 11283 & 1.58 \\
\hline C3S4 & 29366 & 11466 & 1.64 \\
\hline C3S5 & 25670 & 6120 & 1.31 \\
\hline C3S6 & 24870 & 6970 & 1.39 \\
\hline
\end{tabular}

\section{Productive tillers}

Significantly higher number of productive tillers were found with July $2^{\text {nd }}$ FN sowing (5.46). The next highest was found with July $1^{\text {st }}$ FN sowing (5.12). Among different small millets the highest number of productive tillers was found in little millet (5.67) and was on par with prosomillet (5.61). The reason might be due to crop sown early may enjoy favourable micro-climatic conditions in terms of temperature and other climatic parameters during various crop growth stages and ensures better growth of the crop in critical stages and thus reflected in yield. Similar results were observed by Andhale et al., (2007 b), Patel et al., (2004).

\section{Days to maturity}

The days to maturity varied among small millet crops. Little millet crop matured in 92 
days. Prosomillet in 75 days and foxtail millet in 74 days. With respective to sowing windows the days maturity was not significantly influenced (Table 2).

\section{Harvest index}

Harvest index was not significantly influenced by small millet crops and sowing windows

\section{Grain yield}

Among different small millets tested significantly higher grain yield was recorded with the small millet crop, foxtail millet (2679 $\mathrm{kg} / \mathrm{ha})$ followed by little millet $(1823 \mathrm{~kg} / \mathrm{ha})$ however it was on par with proso millet (1564 $\mathrm{kg} / \mathrm{ha}$ ). With respective to sowing windows significantly higher grain yield was recorded when small millet crops are sown during July $2^{\text {nd }} \mathrm{FN}$ ( $\left.2455 \mathrm{~kg} / \mathrm{ha}\right)$ followed by July $1^{\text {st }} \mathrm{FN}$ sowings (2180 kg/ha). Rao et al., (1991) also confirmed that there is decline in grain yield of small millets with delay in sowing

\section{Effect of interaction on grain yield}

Maximum grain yield of foxtail millet and prosomillet were recorded when sown during July $2^{\text {nd }} \mathrm{FN}(3530 \mathrm{~kg} / \mathrm{ha}$ and $1876 \mathrm{~kg} / \mathrm{ha}$ respectively). But for little millet the highest grain yield was observed when sown at July $1^{\text {st }} \mathrm{FN}(2024 \mathrm{~kg} / \mathrm{ha})$. The crop sown in july $2^{\text {nd }}$ FN exposed to congenial microclimate viz., significantly more absorption of photosynthetically active radiation (PAR) resulted in higher light use efficiency (LUE) ultimately increasing photosynthetic rate and significant improvement in important growth and yield attributes. Delayed sowing results in adverse situation of all these parameters by late sown crops and resulted in decreased values of these yield contributing characters. Similar results were envisaged by Kaushik and Gautam (1984), (Siddig et al., 2013) and (Maiti and Soto, 1990).

\section{Straw yield}

Among 3 small millets foxtail millet has given higher straw yield (2679 kg/ha). The next highest was with little millet (2628 $\mathrm{kg} / \mathrm{ha}$ ). The lowest was recorded with prosomillet. Straw yield of small millets were found to be highest sown during $2^{\text {nd }} \mathrm{FN}$ (2987 $\mathrm{kg} / \mathrm{ha}$ ) followed by July $1^{\text {st }} \mathrm{FN}$ sowings (2882 $\mathrm{kg} / \mathrm{ha})$

\section{Economics}

The highest gross returns (66356 Rs./ha), net returns (48456 Rs./ha) and B:C ratio(3.71) were found to be highest when foxtail millet sown during July $2^{\text {nd }} \mathrm{FN}$ followed by foxtail millet sown during July $1^{\text {st }} \mathrm{FN}$ sowings with Rs. $32920 \mathrm{ha}^{-1}$ and $2.68 \mathrm{~B}: \mathrm{C}$ ratio. The reason might be due to higher yield of foxtail millet sown during July $2^{\text {nd }}$ FN. The results are in confirmation with findings of Sukhadia and Dhoble (1992) (Table 3).

From the present study, it can be inferred that for getting higher profitable production in terms of yield and economics, small millets should be sown during July month in kharif. The appropriate time sowing is essential for getting higher yields. Early sown crops relatively gives higher yield attributes and yield. Yield reduction was clearly observed in late sown crops.

\section{References}

Andhale, R.P., Shinde SH, Sinare B.T, Tambe A.D (2007b). Effect of sowing dates and fertilizer levels on phenology and heat unit accumulation in pearlmillet (Pennisetum glaucum L.) hybrids. J. Maharashtra Agric. Univ. 32(3):401402

Kaushik, S.K. and Gautam, R.C. 1984. Effect of varying dates of planting and row spacing on yield of pearl millet varieties under rainfed conditions. Indian $\mathrm{J}$. 
Agron. 29 (3): 480-484.

Maiti, R.K., Soto, G.G. Effect of four sowing date environments on growth, development and yield potentials of 15 pearl millet cultivars (Pennisetum americanum L Leeke) during autumn winter seasons in Marin, N.L., Mexico. Arpn. J. 1999; 3(3): 30-37.

Meaking, I. 1979. Garlic time of planting demonstration Rural Newsletter No. 7127 of Hort. Abstract 50 (8)

Patel, A.M., Patel, D.R., Patel, G.A and Thakor, D.M. 2004. Optimization of sowing and fertilizer requirement of barley (Hordeum vulgare) under irrigated condition. Indian J. Agron. 49(3):171-173.

Rao, K.L., Raja, D.V and Rao, C.P. 1991. Effect of planting time and plant population on growth and yield of fingermillet (Eleusine coracana Gaertn.) varieties. Ann. agric. Res., 12 (1): 14

Siddig AMA, Adam KII, Bahar AH, Hassan
Tha. 2013. Effect of sowing date and variety on growth and yield of pearl millet (Pennisetum glaucum L.) grown on two soil types under rain - fed condition at Zalingei Area in Sudan. Journal of Science and Technology. 20: 3(4).

Sukhadia, N.M., Dhoble, M.V.1992. Productivity and water-use efficiency of rainy-season crops under different dates of sowing. Indian J. Agron. 37(4):669675

Thompson, H.C. and Kelly, W.C. 1957. Vegetable Crops. McGraw Hill Book Company Inc. NY 611p.

Upadhyay, P.N., Dixit, A.G., Patel, J.R and Chavda, J.R. 2001. Response of summer pearlmillet to time and method of planting, age of seedling and phosphorus grown on loamy sand soils of Gujarat. Indian J. Agron. 46(1):126130.

\section{How to cite this article:}

Jyostna Kiranmai, M., S. Saralamma and Chandra Mohan Reddy, C. V. 2021. Assessing the Influence of Sowing Windows on Growth and Yield of Small Millets. Int.J.Curr.Microbiol.App.Sci. 10(02): 939-944. doi: https://doi.org/10.20546/ijcmas.2021.1002.111 